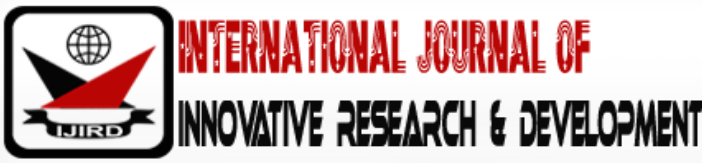

ISSN 2278 - 0211 (Online)

\section{The Duration in School and Academic Performance: A Comparative Study of the Three and Four Year Senior High School Education in Ghana}

\author{
Faustina Akosua Agyeiwaa Kwofie \\ Assistant Secretary, Methodist College of Education, Akyim Asene-Aboabo, Akyim Oda \\ Dominic Kwaku Mensah \\ Director, Department of Teacher Education and Professional Development, \\ University of Education, Winnebago \\ Reverend Isaac Kwofie \\ Head Teacher, Mumford Methodist Primary School, Mumford
}

\begin{abstract}
:
This study investigated the duration in school and academic performance. This was a comparative study of the 3 and 4-year education duration in Ghana. The purpose of the study was to determine which of the two durations of SHS (3-year or 4-year) had positive influence on students' academic performance, in the three selected schools. The quantitative method was used for the study. A population of 5836 students and 149 teachers who taught both the 3 and 4-year SHS students and 3 headmasters were drawn from three schools in Central Region via census, purposive sampling techniques respectively. The documentary checklist and structured questionnaires were used to collect the data. The raw WASSCE scores of 5836 students and the questionnaire data were analysed quantitatively with SPSS. One research question and two hypotheses were formulated to guide the study. Mean and standard deviations, frequencies, independent and paired sample t-test, and oneway were used to analyse the data. The major findings of the study were that the duration of schooling has a positive effect on students' academic performance and the 4-year cohorts of students performed better than the 3-year cohorts. The MOE and GES should consider the 4-year duration as a better suited duration for SHS education in Ghana and should therefore be implemented again.
\end{abstract}

Keywords: Academic, performance, duration, senior high school

\section{Introduction}

The quality of students' performance remains at top priority for educators and policy makers. Educators, trainers, and researchers have long been interested in exploring factors contributing effectively to quality academic performance of learners. These factors may be termed as student factors, teacher factors and school/institutional factors (Crosnoe, Johnson \& Elder, 2004). Besides other factors, duration of schooling is one of the debated factors among educational professionals that contribute towards the academic performance of students. For this, few countries such as the United States of America, Germany and the United Kingdom have extended their primary and secondary school days, compared to an OECD average school day in Europe (Marcotte \& Hansen, 2010). For example, because of the United States' concerns about the performance of American students, extending the length of the school year was a major policy recommendation of a 1983 presidential commission in its report "A Nation at Risk" and has not changed until now (Marcotte \& Hansen, 2010). The role of time as an educational input became an even bigger focus of a second commission a decade later, in a report entitled "Prisoners of Time" (Farbman \& Kaplan, 2015). Despite the important role time plays in school and in the policy debate there is little evidence to what degree the length of the school year matters for academic performance of students. This research, investigates the impact of two policy reforms in the Ghana senior high school (SHS) system which dramatically changed the duration of SHS education in 2007 and 2009.

According to Farbman and Kaplan (2005), the relationship of time to learning is neither as direct nor as simple as it might seem. It is a complex and intriguing equation, with results depending largely on the importance educators attached to time as an education resource. The question of time in education, specifically how much to require, has been visited 
periodically throughout the history of the Ghanaian education. Policymakers have made a lot of reforms either to increase or reduce time as a lever for higher academic performance.

Due to the education reforms in Ghana in 1987, the JSS system, replaced the four-year middle school system. The three-year Senior Secondary School (SSS) system also replaced the seven-year secondary school system which comprised five years of the General Certificate Examination (GCE) Ordinary-Level and two years GCE Advanced-Level (Akyeampong, 2011).

The Senior high school's curriculum lasts for 3 years. As a result of numerous reforms, an originally three-year curriculum was extended to 4 years in 2007 (Acquaye, 2009). However, early 2009 another reform made SHS a 3-year curriculum again (Addo, 2014). The length of the SHS is still a disputed question. In 2007, the Government of Ghana recommended the duration for SHS education to be increased from three years to four years. This recommendation generated a lot of public debate, which culminated in the government having to organize a national forum on the duration of second cycle education, in order to build a national consensus. The 2008 Education Act (Act 778) made the SHS education four years (Akyeampong, 2011).

The Presidential Commission on Education Report's conclusions, in reference to the 3-year duration, was conditional and listed deficiencies to be addressed before its implementation. These deficiencies were: adequate teaching and learning facilities, poor infrastructural facilities, low number of well-motivated and committed teachers and poor management and supervision. It also strongly recommended the provision of adequate human and material resources in all SHS in the country so that no school was disadvantaged. It then concluded that if these deficiencies were addressed, there would be no need to increase the duration (Commission's Report) (Sakyi, 2011). However, since it would be very difficult to meet those criteria in the minimum possible time, the best option according to the committee was to increase the duration to four years.

It is important however to know the justification for the government's decision to amend the four-year duration. The reasons were that: kindergarten education had been mainstreamed, efforts were being made by stakeholders to provide human and material resources, measures were being taken to address teacher distribution and capacity to deliver the syllabuses and the curriculum, infrastructure and equipment were being addressed. There is no doubt that those reasons being adduced for the reduction of the SHS to 3 years were arguably futuristic propositions and not based on what really existed in the school system at that moment.

The key argument for this policy was that the four-year programme was not the solution to poor performance in some schools. Rather, Ghana needed to strengthen the JHS with qualified teachers and infrastructure to lay a good foundation for the students at the SHS (Acquaye, 2009). With the changing from one policy to the other, none of the policies have indicated whether the change affected performance positively. However, there have been several political, educational and societal debates that the four-year SHS performed better than the three-year SHS (Akyeampong, 2011). This is what this research seeks to investigate.

\subsection{Statement of the Problem}

A lot of uncertainties surround the duration of SHS educational provision in the country in terms of academic performance of students. This is epitomized by the policy debate associated with the subject. The study therefore intends to investigate which of the two streams (three years or four year) can yield a better academic performance for students in the second cycle institutions.

\subsection{Purpose of the Study}

The purpose of the study is to determine which of the two durations of SHS (three years or four years) has positive influence on students' academic performance and better suited for SHS education in the three selected schools.

\subsection{Objectives of the Study}

This study is set out to achieve the following objectives. To

- Examine the effect of the duration of SHS education on the academic performance of the 3-year and 4-year SHS cohorts in the WASSCE results in the three selected schools.

- Determine which of the two durations of SHS education is better suited for SHS education in the selected three selected schools.

\subsection{Research Question}

- What is the effect of the duration of SHS education on academic performance of the 3-year and 4-year SHS students in the three selected schools?

\subsubsection{Hypotheses}

- $\mathrm{Ho}_{1}$ There is no significant difference between the academic performance of the 3-year and the 4-year SHS students in the WASSCE in the three selected schools.

- $\mathrm{Ho}_{2}$ There is no significant difference between the performance of 3 year and 4-year SHS students from the same school. 
The study was based on human capital development theory. Human capital theory holds that the well-being of a society is a function of the knowledge and skills of individuals within it. The theory predicts that increased knowledge and skill will yield improved economic outcomes for both individuals and societies. Sweetland (1996) traces the origins of human capital theory to the work of Adam Smith in the $18^{\text {th }}$ century and John Stuart Mill in the 19th. Education is a key element of human capital theory because it is viewed as the primary means of developing knowledge and skill. Some evidence exists to indicate that educational performance, in the form of grades achieved or literacy indicators, have an effect on economic returns independent of attainment. The greatest impact of achievement lies not directly on economic returns but on access to higher levels of education (Frazis, 2002).

In particular, grades achieved in secondary level of schooling are the key determinant of admission to universities and colleges where, arguably, the greatest individual economic benefits can be acquired. Investigating the determinants of students' performance is thus key to understanding the relationship of education to human capital development. More specifically, this study focuses on human capital theory as a conventional model of educational resources as input and students' performance in WASSCE as outcome. It examines education resource allocations as inputs with educational attainment and performance as outcomes. The applicability of the theory in the study can be seen in the fact that all the theoretical concepts: inputs, process and output/outcomes, have a bearing on students' performance. Using the theory, the study sought to investigate the duration of schooling as a factor that affect the desired academic performance of SHS students in three selected SHS.

Students performing well in the final examination (WASSCE) is an indication that a great deal of knowledge have been acquired by them. This also means that quality human capital needed for economic, political and social development of any country. Thus, students performing better in English, mathematics, integrated science, and social studies which students need to pass well before they gain admission into tertiary institutions can help to fill in the human resources needed in Ghana first and the world at large. This makes the theory very relevant and fit for the study.

\section{Methodology}

This study adopted quantitative research design. It involves the collection and analysis of quantitative. The research was conducted in three public schools in the Central Region of Ghana, namely, Winneba Senior High School and Potsin Senior High School as well as Apam Senior High School. The census sampling method was used to select the entire population of the 2011, 2012, 2014 and 2015 WASSCE candidates and since this aspect involved students' results, no part of the population was left unanalysed. 105 teachers and 3 headmasters who had taught the year groups under investigation were selected with purposive sampling and convenience sampling methods respectively to answer the structured questionnaire.

The raw score of WASSCE results document and the result from the quantitative survey were analysed and interpreted using Statistical Product for Service Solution (SPSS) version 20. Descriptive statistics such as means, standard deviations, frequencies and percentages were used to answer the research question, and the first hypothesis was tested using the paired sample t-test whiles the second research hypotheses was tested using t-test and one-way ANOVA.

\section{Discussions and Findings}

\subsection{Effect of Duration of SHS Education on Students' Academic Performance}

The research question sought to find out whether the duration of SHS education had any effect on academic performance of the 3-year and 4-year SHS students. The 105 teachers and the 3 headmasters were asked to indicate their agreement or otherwise on a number of items on how duration affects students' academic performance. It was clear that duration has effects on students' academic performance and the result is presented in table 4.6. The data discussed in this section seeks to find answers to research question which states "What is the effect of the duration of SHS education on academic performance of the 3-year and 4-year SHS students in the three selected schools?"

\begin{tabular}{|c|c|c|c|c|c|c|c|c|}
\hline \multirow[t]{3}{*}{ Items } & \multicolumn{4}{|c|}{3 years } & \multicolumn{4}{|c|}{4 years } \\
\hline & \multicolumn{2}{|c|}{ A } & \multicolumn{2}{|c|}{$\mathrm{D}$} & \multicolumn{2}{|c|}{ A } & \multicolumn{2}{|c|}{$\mathrm{D}$} \\
\hline & $\mathrm{N}$ & $(\%)$ & $\mathrm{N}$ & $(\%)$ & $\mathrm{N}$ & $(\%)$ & $\mathrm{N}$ & $(\%)$ \\
\hline Teachers have enough time to complete the syllabus & 12 & 11.1 & 96 & 88.9 & 108 & 100 & - & - \\
\hline Students have adequate time to complete the syllabus & 12 & 11.1 & 96 & 88.9 & 108 & 100 & - & - \\
\hline $\begin{array}{c}\text { Students have enough preparation before the final } \\
\text { WASSCE examination }\end{array}$ & 27 & 25.0 & 81 & 75 & 96 & 88.9 & 12 & 11.1 \\
\hline $\begin{array}{c}\text { Students performed well in the Student Based } \\
\text { Assessments }\end{array}$ & 86 & 79.6 & 22 & 20.4 & 102 & 94.4 & 6 & 5.6 \\
\hline Students performed well in the WASSCE examination & 39 & 36.1 & 69 & 63.9 & 102 & 94.4 & 6 & 5.6 \\
\hline Mean & 35.2 & 32.6 & 72.8 & 67.42 & 103 & 95.5 & 4.8 & 4.5 \\
\hline
\end{tabular}

Table 1: School Duration and Academic Performance

Source: Field Data, $2016 \mathrm{~N}=108$

Key: $A=$ Agree, $D=$ Disagree, $N=$ Number, $\%=$ Percentage 
In examining whether the duration has effect on academic performance, respondents shared their views on various activities that take place in the school. The respondents' views are represented in table 1 . With regards to teachers having enough time to complete the SHS syllabus, data shows that during the 3-year period, majority $(88.9 \%)$ teachers do not have enough time to be able to complete the syllabus whiles during the 4-year period, all teachers $(100 \%)$ agreed that the period gave teachers the ample time to complete the syllabus fully. Further, data revealed that on the part of students, they did not have adequate time to complete the syllabus as in the case of the teachers. $88.9 \%$ indicated that the 3-year period did not favour students to complete what they are expected to know as stipulated in the syllabus. On the other hand, majority (100\%) of the teachers affirmed that the 4-year period gave the students the needed time to be able to complete what is expected of them to know at that level of education.

Similarly, on the subject of whether students have enough preparation before the final WASSCE examination, data presented in table 8 indicated that $75 \%$ were of the view that students in the 3-year period did not have adequate time to prepare as compared to their counterparts in the 4 years (88.9\%). Majority (94.4\%) of the teachers were in agreement that students in the 4-year period of SHS education performed well in the Student Based Assessments organised as compared to their counterparts in the 3-year group. However, $79.6 \%$ of teachers agreed that students in the 3-year period also performed well in the student-based assessment. With regards to students' performance in the WASSCE examination, majority (94.4\%) of teachers as in the case of the student-based assessment indicated that the students in the 4-year cohort did extremely well. $63.9 \%$ of teachers disagreed that students in the 3-year period performed well in the WASSCE examination. Comparing the School Based Assessment in this perspective, data in table 1 suggest that students in the 3 years did well but did not do well in the WASSCE examination. However, with the 4-year period, the same percentage (94.4\%) of teachers recorded affirmed that performed of students were encouraging.

Drawing inference from the collated data displayed in table 1 above, one can conclude that the 4-year period gave teachers and students enough time to complete the syllabus and prepared adequately for the School Based Assessment and that of the WASSCE examination which is translated into good results as compared to their counterparts who went through the 3-year period. It must also be stated that even though students in the 3year period did not have time to complete the syllabus their performance in the School Based Assessment was encouraging but failed to translate the same performance in the WASSCE examination.

The results confirm the study of Krashinsky (2006), who reported that the longer duration of school years provide the potential for increased instruction time, review, and attention for individual students. Eren and Mittlemet (2005) also found out that the best performing students benefit from longer school years. Similar results were obtained by Ukpong and George (2013) who investigated the length of study time and academic performance of Social Studies Education students in the University of Uyo. Their study revealed that extended duration of learning improves students' academic performance. Again, Hansen (2008) who investigated the impact of instructional days on student performance and concluded that more instructional time prior to test administration increases student performance.

However, the result is in contrast to the findings of Pischke (2003) who looked at the short school years mandated in Germany to unify their schooling system and concluded that shorter school years increase grade repetition rather than improving performance. Also, Skirbekk (2006) assessed how the duration of primary and secondary schooling affects student performance in the final year of secondary school in Switzerland and concluded that there was no significant impact of the school duration on student performance in mathematics and science tests scores. Young and Berger (1983), Pittman, Cox, and Burchfiel (2010) who also studied the changes in achievement that can be expected from extending the school year found out that extending the school year will not result in improved or better academic performance.

From the results of table 1 and the discussions above it can therefore be concluded that duration has great effect on academic performance of students as teachers and students have enough time to complete the syllabus, students have enough preparation before the final WASSCE examination, perform well in the School Based Assessments, as well as in the final WASSCE examination in the 4-year (extended) duration than the 3-year (shorter) duration.

Following the analysis, interpretation and discussion of the results of the research question, it was established from the study that the duration has great effect on academic performance of 3 year and 4-year SHS students. While 95.5\% respondents strongly agreed that duration was the major factor that caused the better performance of 4 year as teachers and students have enough time to complete the syllabus, students have enough preparation before the final WASSCE examination, performed well in the School Based Assessments, as well as in the final WASSCE examination in the 4-year (extended) duration, only $4.5 \%$ agreed that the 3-year (shorter) duration improved students' academic performance.

\subsection{Academic Performance of the 3-Year and 4-Year SHS Students in WASSCE}

The overarching objective of this study is to establish a difference between the 3 year and the 4-year students' performance scores on the WASSCE results in the selected SHS in the Central Region of Ghana. The results of the hypothesis one is presented in tables 11 and 12 . The data under this section seeks to discuss the hypothesis 1 which states that "There is no significant difference between the academic performance of the 3-year and the 4-year SHS students in the WASSCE in the three selected schools. 


\begin{tabular}{|c|c|c|c|c|}
\hline WASSCE Scores & $\mathbf{N}$ & Mean & Std. Deviation & Std. Error Mean \\
\hline 3-Year & 3410 & 5.827 & 1.318 & .027 \\
\cline { 2 - 5 } 4-Year & 2426 & 3.874 & 1.464 & .025 \\
\hline
\end{tabular}

Table 2: Group Statistics for 4-Year and 3-Year WASSCE Results

$N=5836$

Source: Field Data, 2016

The descriptive statistics in table 4.9 reveal that the 4-year group of students performed better with mean score of 3.874 ( $\mathrm{sd}=1.464$ ) which lie between WASSCE grades B3 and C4 than the 3-year group of students with mean score of 5.827 $(\mathrm{sd}=1.318)$ which lie between grades C5 and C6. It is therefore clear from the above results a 17\% ( $\mathrm{n}=984)$ differential due to variations of candidates in the randomised schools for the study. Similarly, 1.95 means difference exist between the two-year groups on their respective examination scores in this study with .02 standard error on means as well.

\begin{tabular}{|c|c|c|c|c|c|c|c|c|c|}
\hline \multirow{3}{*}{ WASSCE Results } & \multicolumn{2}{|c|}{$\begin{array}{c}\text { Levene's Test } \\
\text { for Equality of } \\
\text { Variances }\end{array}$} & \multicolumn{7}{|c|}{ T-Test for Equality of Means } \\
\hline & \multirow[t]{2}{*}{$\mathrm{F}$} & \multirow[t]{2}{*}{ Sig. } & \multirow[t]{2}{*}{$\mathrm{T}$} & \multirow[t]{2}{*}{ Df } & \multirow{2}{*}{$\begin{array}{c}\text { Sig. } \\
(2-\text { tailed })\end{array}$} & \multirow{2}{*}{$\begin{array}{l}\text { Mean } \\
\text { Diff. }\end{array}$} & \multirow{2}{*}{$\begin{array}{l}\text { Std. Error } \\
\text { Diff. }\end{array}$} & \multicolumn{2}{|c|}{ 95\% CIDiff. } \\
\hline & & & & & & & & Lower & Upper \\
\hline Equal variances & 24.442 & .000 & -52.320 & 5834 & .000 & -1.953 & .0373 & -1.880 & -2.026 \\
\hline $\begin{array}{l}\text { assumed } \\
\text { Equal variances not } \\
\text { assumed }\end{array}$ & & & -53.253 & 5524 & .000 & -1.953 & .0367 & -1.881 & -2.025 \\
\hline
\end{tabular}

Table 3: Independent Samples Test for 4-Year and 3-Year WASSCE Results

$N=5836$

Source: Field Data, 2016

According Howell (2010), standard errors represent a variable in sampling. However, the samples variations on their mean scores were inconsistent and violated the assumption of homegeneity of variance test $(F(5834)=24.44, p<.05)$ in table 2 above. The significant value, $\mathrm{p}<.05$ implies that the variances for the two groups are not same and therefore the data violates the assumption of equal variance. Thus, two-tailed on their WASSCE mean scores of the 4 year and 3-year students differed significantly $(\mathrm{t}(5524)=-53.253, \mathrm{p}<.05)$, leading to the rejection of the null hypothesis 1 that the two groups WASSCE performance scores would not differ statistically. Additionally, the mean difference of 1.95 can be accounted for $95 \%$ of the time between 1.88 (lower) and 2.03 (upper).

The results showed there is statistical difference between the scores of the 3-year and 4-year students in WASSCE results with $(\mathrm{t}(5524)=-53.253, \mathrm{p}<.05)$, two-tailed on their WASSCE mean scores. Thus the 4-year group performed better with mean score of $3.874(\mathrm{sd}=1.404)$ which lie between grade B3 and C4 than the 3-year group with mean score of 5.827 ( $\mathrm{sd}=1.318)$ which lie between grade $\mathrm{C5}$ and C6.

\subsection{Performance of 3-Year and 4-Year SHS Students from the Same School}

Research hypothesis 2 sought to examine the significant differences between the 3 year and 4-year cohorts performance in the three schools selected for the current study using their WASSCE test scores. Table 4 shows the descriptive statistics for the schools with their respective SD, SE, and CI statistics. The data under this section seeks to discuss the hypothesis 4 which states that "There is no significant difference between the performance of 3 year and 4-year SHS students from the same school."

\begin{tabular}{|l|c|c|c|c|c|c|c|c|}
\hline & N & Mean & \multirow{2}{*}{$\begin{array}{c}\text { Std. } \\
\text { Deviation }\end{array}$} & $\begin{array}{c}\text { Std. } \\
\text { Error }\end{array}$ & \multicolumn{2}{|c|}{$\begin{array}{c}\text { 95\% Confidence } \\
\text { Interval for Mean }\end{array}$} & Minimum \\
\cline { 3 - 7 } & & & & & $\begin{array}{c}\text { Lower } \\
\text { Bound }\end{array}$ & $\begin{array}{c}\text { Upper } \\
\text { Bound }\end{array}$ & \\
\hline School A 3yrs & 2039 & 5.26 & 1.583 & .035 & 4.19 & 4.33 & 1.00 & 10.50 \\
\hline School A 4yrs & 2039 & 3.38 & 1.449 & .031 & 3.25 & 3.27 & 1.00 & 10.65 \\
\hline School B 3yrs & 2135 & 4.81 & 1.729 & .037 & 4.73 & 4.88 & 1.00 & 8.75 \\
\hline School B 4yrs & 2135 & 3.59 & 1.635 & .033 & 3.81 & 3.77 & 1.00 & 8.56 \\
\hline School C 3yrs & 1662 & 5.86 & 1.702 & .042 & 4.97 & 5.14 & 1.00 & 8.75 \\
\hline School C 4 yrs & 1662 & 4.47 & 1.582 & .039 & 4.27 & 4.68 & 1.00 & 8.63 \\
\hline
\end{tabular}

Table 4: Descriptive of WASSCE Performance Scores for 3 Year and 4-Year Groups in the Selected Schools in This Study

Source: Field Data, 2016 
The results in table 4 indicate that the 4-year groups performed better in the WASSCE scores than the 3-year groups in all the three schools - school C, school B and school A in this study. Thus, the average grade scored by 4-year group in school C was C4 (Mean=4.47; sd=1.582) compared with C6 (Mean=5.86; $s d=1.702)$ for the 3-year group in the same school. For school B while the 4-year group scored mean grade of C4 (Mean=3.59; sd=1.635), the 3-year groups scored C5 (Mean=4.81; $s d=1.729$ ). Also, in school A while the 4-year group average score is B3 (Mean=3.38; $s d=1.449$ ), the average score for the 3year group was C5 (Mean =5.26; sd=1.583).

\begin{tabular}{|c|c|c|c|c|c|}
\hline WAEC Scores (2011-2015) & Sum of Squares & Df & Mean Square & F & Sig. \\
\hline Between Groups & 633.331 & 2 & 316.665 & 113.325 & .001 \\
\hline Within Groups & 16299.281 & 5833 & 2.794 & & \\
\hline Total & 16932.612 & 5835 & & & \\
\hline
\end{tabular}

Table 5: One-Way ANOVA Test for the 3-Year and 4-Year Cohorts in the Three Schools in This Study $N=5836$

Source: Field Data, 2016

Based on the descriptive statistics in table 5, the study showed that indeed, the mean differences observed in the 3 year and 4-year groups performance across the three randomised schools were significant $(F(2)=113.31, p<.05)$. Therefore, the study rejects the null hypothesis 3 and concludes that the WASSCE results for the 3 year and 4-year groups from the selected schools in this study statistically differed.

\begin{tabular}{|c|c|c|c|c|c|c|}
\hline \multirow{2}{*}{$\begin{array}{l}\text { (I) Index } \\
\text { Number }\end{array}$} & \multirow{2}{*}{$\begin{array}{l}\text { (J) Index } \\
\text { Number }\end{array}$} & \multirow{2}{*}{$\begin{array}{l}\text { Mean Difference } \\
\text { (I-J) }\end{array}$} & \multirow{2}{*}{$\begin{array}{l}\text { Std. } \\
\text { Error }\end{array}$} & \multirow[t]{2}{*}{ Sig. } & \multicolumn{2}{|c|}{ 95\% Confidence Interval } \\
\hline & & & & & Lower Bound & Upper Bound \\
\hline \multirow[t]{2}{*}{ School A } & $\mathrm{B}$ & $24676^{*}$ & .05468 & .000 & .1186 & .3749 \\
\hline & $\mathrm{C}$ & $.79792^{*}$ & .05524 & .000 & .6684 & .9274 \\
\hline \multirow[t]{2}{*}{ School B } & A & $-.24676^{*}$ & .05468 & .000 & -.3749 & -.1186 \\
\hline & $\mathrm{C}$ & $.55117^{*}$ & .05176 & .000 & .4298 & .6725 \\
\hline \multirow[t]{2}{*}{ School C } & $\mathrm{A}$ & $-.79792^{*}$ & .05524 & .000 & -.9274 & -.6684 \\
\hline & $\mathrm{B}$ & $-.55117^{*}$ & .05176 & .000 & -.6725 & -.4298 \\
\hline
\end{tabular}

Table 6: Tukey HSD Test for Multiple Comparisons between Schools

*. The Mean Difference Is Significant at the 0.05 Level. Dependent Variable: WASSCE Scores

Source: Field Data, 2016

$N=5836$

The post-hoc results in table 6 above illustrate significant differences exist between School A and B ( $\mathrm{p}<.05), B$ and $\mathrm{C}(\mathrm{p}<.05)$, and; A and C ( $<<.05)$. Practically, all the three schools' WASSCE results obtained between 2011 and 2015 differed between the three senior high schools in the municipality.

There is significant difference between the average grade score of the 3-year groups and 4-year groups in the same schools. In school C, the average grade score was C4 (Mean=4.47; sd=1.582) for the 4-year group compared with C6 (Mean=5.86; sd=1.702) for the 3-year group in the same school. For school B while the 4-year group scored mean grade of C4 (Mean=3.59; sd=1.635), the 3-year groups scored C5 (Mean=4.81; sd=1.729). Also, in school A while the 4-year group average score is B3 (Mean=3.38; sd=1.449), the average score for the 3-year group was C5 (Mean =5.26; sd=1.583). Again, the mean differences observed in the 3 year and 4 year groups performance across the three randomised schools were significant $(F(2)$ $=113.31, \mathrm{p}<.05$ ).

It study noted from the study that duration of schooling has a positive effect on students' academic performance. Thus, the longer duration (4 years) gives students and their teachers ample time to complete the syllabus, prepare well for WASSCE examination which enable them to pass well (Pederson, 2010). This was also evidenced in the general performance scores in the WASSCE results of the two cohorts and in the individual core subjects. The results showed there is statistical difference between the scores of the 3-year and 4-year students in WASSCE results. Also, the 4-year group performed better than the 3-year group in the core subjects - language, integrated science, mathematics and social studies

It is also, established from the study that the duration has great effect on academic performance of students' 3 year and 4-year SHS education. Majority of the respondents strongly agreed that duration was the major factor that caused the better performance of 4 year as teachers and students have enough time to complete the syllabus, students have enough preparation before the final WASSCE examination. They indicated that the students performed well in the School Based Assessments, as well as in the final WASSCE examination in the 4-year (extended) duration than the 3-year (shorter) duration (Ukpong and George, 2013). 


\section{Conclusion}

It can be concluded from the analyses so far that the duration of schooling had positive effect on the academic performance of the student who had their SHS education in 4 years (extended duration). The extended duration of schooling made the students performed better in WASSCE results than those who complete in 3 years (shorter duration).

\section{Recommendation}

Following the research findings and conclusions, it is recommended that the Ministry of Education and Ghana Education Service should consider the 4-year duration as a better suited duration for SHS education in Ghana and should therefore be implemented again.

\section{References}

i. Acquaye, E. (2009). "Why Ghana returned to three-year Senior High School". http://www.modernghana.com/news/230835/1 (Retrieved 12/05/2016).

ii. Addo, K. C. (2014). Breaching the Latent Value of Education System: A Cardinal Cause of the Present State of High Unemployment Rate in Ghana? Catholic University College of Ghana. http://www.spyghana.com/tag/breaching. (Retrieved 04/07/2016).

iii. Akyeampong, K. (2011). Educational expansion and access in Ghana: A review of 50 years of challenge and progress. Centre for International Education, U.K: University of Sussex.

iv. Crosnoe, R., Johnson, K. M., \& Elder, H. G. (2004). School size and the interpersonal side of education: An examination of race/ethnicity and organizational context. Social Science Quarterly, 85(5), 1259-1274.

v. ${ }^{* * *}$ Erhrenberg, G. R., Brewer, J. D., Gamoran, A., \& Willms, J. D. (2001). 'Does class size matter'. Scientific American, 285. www.sceintificamerican.com (Retrieved 23/08/2016).

vi. Farbman, D., \& Kaplan, C. (2005). Time for change: The promise of extended-time schools for promoting achievement. http://www.mass2020.org/. (Retrieved 03/05/2016).

vii. Frazis, Harley (2002). "Human capital, signaling, and the pattern of returns to education". Oxford Economic Papers $54(1), 298-320$.

viii. Hansen B. (2008). School year length and student performance: Quasi-experimental evidence. Department of Economics, University of California, Santa Barbara: University Press.

ix. Howell, D. C. (2010). Statistical methods for psychology. (7th ed.). Canada, Belmont: Thomson/Wadsworth.

x. Krashinksy, H. (2006). "How would one extra year of high school affect performance in University? Evidence from a Unique Policy Change," mimeo.

xi. Marcotte, D. E., Hansen, B. (2010). Time for school? Education Next, 10 (1), 53-59.

xii. Pischke, J. S. (2003). The impact of length of the schooled year on student performance and earnings: evidence from the German short school years." NBER Working Paper 9964.

xiii. Pittman, R., Cox, R., \& Burchfiel, G. (2010), The extended school year: Implications for student achievement. Western Carolina University.

xiv. Sakyi, K. A. (2011). "Is our educational system in Ghana globally competitive?" www.ghanaweb.com/GhanaHomePage/News (Retrieved 14/06/2016).

xv. Skirbekk, V, (2006). Does school duration affect student performance? Findings from canton-based variation in Swiss Educational length. Schweizerische Zeitschrift fur Volkswirtschaft und Statistik, 142 (1), 115-145.

xvi. Sweetland, S.R. (1996). Human capital theory: Foundations of a field of inquiry. Review of Educational Research, 66 (3), 341-359.

xvii. Ukpong, D. E., \&. George, I. N (2013). Length of study-time behaviour and academic achievement of social studies education students in the University of Uyo. Nigeria, Akwa Ibom State: University of Uyo. http://dx.doi.org/10.5539/ies v6 n3p172 Retrieved: May 14, 2016

xviii. Young, R., \& Berger, D. (1983). Evaluation of a year-round Junior School operations. NASSP Bulletin, 67, 53-59. 